\title{
$\begin{array}{lllllllllllllllll}\mathbf{R} & \mathbf{O} & \mathbf{Z} & \mathbf{P} & \mathbf{R} & \mathbf{A} & \mathbf{W} & \mathbf{Y} & \text { I } & \text { A } & \mathbf{R} & \mathbf{T} & \mathbf{Y} & \mathbf{K} & \mathbf{U} & \mathbf{L} & \mathbf{Y}\end{array}$
}

Prawo Kanoniczne

60 (2017) nr 3

DOI:10.21697/pk.2017.60.3.01

KS. WOJCIECH GÓRALSKI

Wydział Prawa Kanonicznego

Uniwersytetu Kardynała Stefana Wyszyńskiego w Warszawie

\section{RECEPCJA KODEKSU PRAWA KANONICZNEGO Z 1917 ROKU W POLSCE W OKRESIE MIĘDZYWOJENNYM}

Treść: Wstęp. - 1. W doktrynie. - 2. W nauczaniu. - W ustawodawstwie partykularnym. - Zakończenie.

\section{Wstęp}

Promulgowanie przez Benedykta XV w dniu 27 maja 1917 roku bullą Providentissima Mater Ecclesia Kodeksu Prawa Kanonicznego, który wszedł w życie 19 maja 1918 roku, stanowiło doniosły moment w historii ustawodawstwa Kościoła Łacińskiego. Podczas gdy wszystkie poprzednie kolekcje prawa kanonicznego, łącznie z Dekretałami Grzegorza IX, były jedynie kodyfikacjami częściowymi, KPK stanowił kodyfikację pełną. Poza tym, nie była to już tylko zwykła kompilacja, lecz kodeks sensu stricto, upodobniony do nowoczesnych kodeksów państwowych, spełniający wszystkie wymogi stawiane kodyfikacji przez teoretyków prawa. Nic też dziwnego, że ten autentyczny, organiczny, systematyczny, powszechny i ekskluzywny zbiór, stanowiący syntezę dorobku ustawodawczego Kościoła z dziewiętnastu stuleci,

\footnotetext{
${ }^{1}$ Codex Iuris Canonici Pii X Pontificis Maximi iussu digestus Benedicti Papae XV auctoritate promulgatus, AAS 9 (1917), pars II; Codex Iuris Canonici Pii X Pontificis Maximi iussu digestus Benedicti Papae XV auctoritate promulgatus, Praefatione Emi Petri Gasparri et Indice analytico-alphabetico auctus, Typis Polyglottis Vaticanis MCMXVII (CIC).
} 
spotkał się z dużym uznaniem w świecie prawniczym² ${ }^{2}$ Wiążąc umiejętnie nova et vetera, stanowił wyraz z jednej strony nieodzownej ciągłości i stałości, z drugiej zaś szerokiego otwarcia się ku nowym, wciąż zmieniającym się warunkom życia ${ }^{3}$. Znaczącymi czynnikami o charakterze kościelno-politycznym Kodeksu było między innymi prawne ujęcie prymatu papieskiego oraz zamanifestowanie autonomii prawa kościelnego ${ }^{4}$.

W wydanym 15 września 1917 roku motu proprio Cum Iuris Canonici Benedykt XV ustanowił Papieską Komisję Kardynałów do autentycznej interpretacji kanonów Kodeksu, która miała odpowiadać na pytania przedstawiane przez ordynariuszy miejsca i wyższych przełożonych zakonnych ${ }^{5}$.

Promulgacja, a następnie wejście w życie KPK postawiły niełatwe zadanie przed Kościołami lokalnymi funkcjonującymi w poszczególnych krajach, m.in. przed Kościołem w Polsce. Obejmowało ono przede wszystkim gruntowne zapoznanie się, w szczególności przez biskupów diecezjalnych, z regulacjami Kodeksu, a w konsekwencji dostosowanie obowiązującego wówczas prawa partykularnego do tychże regulacji. Recepcja Codex Iuris Canonici w poszczególnych Kościołach partykularnych stała się niezbędna zarówno w duszpasterstwie, jak i w administracji oraz sądownictwie.

Przyswajanie sobie norm kodeksowych przez Kościoły partykularne, głównie na drodze synodalnej, dokonywało się w kontekście wzmożonej aktywności tak doktryny, jak i ośrodków nauczania prawa kanonicznego. Ze zrozumiałych względów obydwa te czynniki odgrywały znaczącą rolę w procesie przenikania do życia kościelnego

\footnotetext{
${ }^{2}$ Cf. U. Stutz, Geist des Codex Iuris Canonici, Stuttgart 1918.

${ }^{3}$ G. Feliciani, Il nuovo Codice tra fedeltà e novità, w: La normativa del nuovo Codice, red. E. Cappelini, Brescia 1983, s. 9-10.

${ }^{4}$ E. Corecco, Die kulturellen und ekklesiologischen Voraussetzungen des CIC, Archiv für Katholisches Kirecenrecht 152(1983), s. 8-11; R. SobańsKi, Teoria prawa kościelnego, Warszawa 1992, s. 124; C. FAnTAPPIÈ, Storia del diritto canonico e delle istituzioni della Chiesa, Bologna 2011, s. 270.

${ }^{5}$ Pontificia Commissio Cardinalium ad Codicis canones authentice interpretandos, AAS 9 (1917), s. 483.
} 
ius novissimum; można powiedzieć, że - w jakiejś mierze - proces ten warunkowały.

Tak się złożyło, że wprowadzanie do życia Kodeksu Pio-Benedyktyńskiego w Polsce zbiegło się z odzyskaniem przez nią, 11 listopada 1918 roku, niepodległości, co ze zrozumiałych względów miało duże znaczenie także dla Kościoła lokalnego, obejmującego 18 diecezji skupionych w trzech metropoliach. Pilne podejmowanie działań w zakresie odbudowywania i reaktywowania wielu struktur kościelnych po 123 latach niewoli narodowej spowalniało tym samym proces recepcji KPK w życiu wewnątrzkościelnym. Niemniej jednak, jak zauważa wybitny historyk Kościoła, H.E. Wyczawski, „w związku z ogłoszeniem nowego Kodeksu we wszystkich diecezjach zabrano się do przystosowania struktury urządzeń kościelnych i całej kościelnej administracji do nowych przepisów. Również wszystkie zakony podjęły w myśl nowego prawa korekturę swoich konstytucji”.6.

Gdy chodzi o trwanie w czasie złożonego procesu recepcji KPK w Polsce, to trudno jest wskazać tutaj termin ad quem, można jednak przyjąć, iż podstawowy okres przyswajania sobie norm tego zbioru obejmował dwudziestolecie międzywojenne, a więc lata 1918-1939; taki też czasokres zostanie uwzględniony w niniejszym opracowaniu.

Co się tyczy natomiast obszarów, w których owa recepcja dokonywała się, to - w myśl tego, co powiedziano wyżej - należy wskazać: doktrynę, nauczanie oraz Kościoły partykularne. Gdy chodzi o te ostatnie, proces recepcji zostanie ukazany na przykładzie diecezji płockiej.

\section{W doktrynie}

Od samego początku KPK wzbudzał żywe zainteresowanie wielu kanonistów, znacząco przyczyniając się do rozwoju nauki prawa kanonicznego, szczególnie w pierwszym dziesięcioleciu obowiązywania tej kodyfikacji. W ślad za pierwszymi podręcznikami i komentarzami,

${ }^{6}$ H.E. Wyczawski, Ogólna sytuacja w Kościele powszechnym i w Państwie polskim, w: Historia Kościoła w Polsce, t. 2, cz. 2 (1918-1945), red. B. Kumor, Z. Obertyński, Poznań-Warszawa 1979, s. 6. 
jakie pojawiły się w Rzymie a następnie również w innych środowiskach $^{7}$, również w Polsce nie zabrakło analogicznych opracowań.

Już w 1917 roku ukazała się praca wybitnego profesora Katolickiego Uniwersytetu Lubelskiego J. Rotha $(+1945)$, absolwenta Wydziału Prawa Kanonicznego Papieskiego Uniwersytetu Gregoriańskiego, „Nowa kodyfikacja prawa kanonicznego”, poświęcona ogólnemu zaprezentowaniu nowego Kodeksu ${ }^{8}$, a w następnym roku jego praca „Nowe prawo kościelne a dawne" 9 . W 1918 roku pojawiło się opracowanie „Nowy Kodeks prawa kanonicznego”, którego autorem był jeden z najwybitniejszych kanonistów polskich, Władysław Abraham (+1941), twórca lwowskiej szkoły historyczno-prawnej ${ }^{10}$. Bardziej szczegółowa prezentacja KPK wyszła w 1927 roku spod pióra B. Żongołłowicza (+1944), profesora w Akademii Duchownej w Petersburgu, a następnie na Katolickim Uniwersytecie Lubelskim: „O kodyfikacji prawa kościelnego"11. Z kolei w 1922 roku L. Halban (+1960), profesor tych samych uczelni, wydał większą pracę, poświęconą zasadom społecznym nowego $\mathrm{KPK}^{12}$.

W upowszechnianiu dyspozycji Kodeksu Pio-Benedyktyńskiego nie tylko w środowiskach akademickich, lecz również wśród pracowników administracji kościelnej, sądownictwa kościelnego oraz licznej rzeszy duszpasterzy znaczącą rolę odegrały podręczniki prawa kanonicznego. Autorem pierwszego z nich był I. Grabowski (+1950), profesor prawa kanonicznego na Wydziale Teologicznym Uniwersytetu

\footnotetext{
${ }^{7}$ Cf. C. Fantappiè, Storia del diritto canonico e delle istituzioni della Chiesa, dz cyt., s. 271-272.

${ }^{8}$ J. Roth, Nowa kodyfikacja prawa kanonicznego, Przegląd Powszechny 136(1917), s. 541-552, 685-695.

${ }^{9}$ Tenże, Nowe kościelne prawo a dawne, Przegląd Powszechny 137-138(1918), s. 33-38.

${ }^{10}$ W. Abraham, Nowy Kodeks prawa kanonicznego, Polonia Sacra 1(1918), s. 1-28.

${ }^{11}$ B. ŻongoŁŁowicz, O kodyfikacji prawa kościelnego, Przegląd Teologiczny 8(1927), s. 1-16; 142-161.

${ }^{12}$ L. Halban, Zasady społeczne nowego kodeksu prawa kościelnego. Próba syntezy, Poznań 1922; Zob. także P. Hemperek, Kanonistyka polska w 60-leciu wolnej Polski (1918-1978), Prawo Kanoniczne 24(1981) nr 1-2, s. 64.
} 
Lwowskiego, a następnie na analogicznym Wydziale Uniwersytetu Warszawskiego. Opublikowany przez niego komentarz do Kodeksu „Prawo Kanoniczne według nowego Kodeksu”', który doczekał się czterech wydań $(1918,1921,1927,1948)$, przez wiele lat był używany przez studentów prawa kanonicznego oraz przez kandydatów do kapłaństwa w seminariach duchownych. Dzieło to obejmowało następujące rozdziały (odpowiadające księgom kodeksowym): Prawo publiczne, Źródła (pomieszczono tutaj m.in. Normy ogólne, czyli Księgę I), Prawo osobowe (Księga II), Prawo rzeczowe (Księga III), Prawo sądowe (Księga IV), Prawo karne (Księga V).

O wiele doskonalszy był kolejny podręcznik, którego autorem był Franciszek Bączkowicz (+1923), wychowanek Papieskiego Uniwersytetu Gregoriańskiego, profesor prawa kanonicznego w Instytucie Teologicznym Misjonarzy św. Wincentego w Krakowie: „Prawo kanoniczne. Podręcznik dla duchowieństwa”. To dwutomowe dzieło, wydane w $1923 \mathrm{roku}^{14}$, stanowiło wnikliwy i pogłębiony komentarz do całego KPK. W swoim drugim wydaniu, uzupełnionym przez J. Barona (+1976) w 1932 roku, podręcznik ten cieszył się dużym uznaniem i miał znaczący wpływ na formację kanonistyczną wielu pokoleń kapłanów w Polsce, stanowiąc wydatną pomoc dla przygotowujących się do kapłaństwa seminarzystów. Z powodzeniem służył również wykładowcom prawa kanonicznego w seminariach. Wychodząc poza podstawowy okres recepcji Kodeksu można wspomnieć, że trzecie, bardzo obszerne (liczące łącznie 2.201 stron), trzytomowe wydanie komentarza, z lat 1957-1958, uzupełnione przez J. Barona i W. Stawinogę $(+1976)^{15}$, stało się niezastąpioną pomocą w studium

\footnotetext{
${ }^{13}$ I. Grabowski, Prawo Kanoniczne według nowego Kodeksu, t. 1-2, Lwów 1918; Prawo Kanoniczne według nowego Kodeksu (w jednym tomie), wyd. 2, Lwów 1921; Prawo Kanoniczne według nowego Kodeksu (w jednym tomie), wyd. 3 poszerzone, Lwów 1927; Prawo Kanoniczne (w jednym tomie), wyd. 4 (uzupełnione i skrócone), Warszawa 1948.

${ }^{14}$ F. BĄсzкowicz, Prawo kanoniczne. Podręcznik dla duchowieństwa, t. 1-2, Kraków 1923.

${ }^{15}$ Tenże, Prawo kanoniczne. Podręcznik dla duchowieństwa, wyd. 3 (uzupełnione przez J. Barona i W. Stawinogę), t. 1, Opole 1957; t. 2 i t. 3, Opole 1958.
} 
ius canonicum dla kolejnych pokoleń przyszłych duszpasterzy. Korzystali zeń obficie również profesorowie tej dyscypliny, nie wspominając o pracownikach administracji kościelnej i sądownictwa kościelnego. Dzieło to, opatrzone obszernym wstępem, uwzględniające historię każdej instytucji i nawiązujące do klasycznych komentarzy takich autorów, jak: F. M. Cappello, M. Conte a Coronata, J. Chelodi, Al. De Smet, P. Gasparri, E.F. Regatillo, A. Vermersch - J. Creusen, A.C. Jemolo, L. Bender czy F.X. Vernz - P. Vidal, nie przestaje być powoływane i we współczesnych opracowaniach. Bez cienia przesady można powiedzieć, że ten systematyczny, obejmujący całokształt norm kodeksowych wykład stanowił - poczynając od lat dwudziestych - podstawowe narzędzie recepcji KPK w Polsce.

Gdy chodzi o ogólne zorientowanie wiernych świeckich w problematyce Kodeksu, to należy wspomnieć pracę M. Wyszyńskiego (+1972), profesora Uniwersytetu Lwowskiego, a następnie Uniwersytetu Wrocławskiego: „Co katolik powinien wiedzieć o prawie kanonicznym"16.

Poza wymienionymi komentarzami do całościowej regulacji kodeksowej, nie zabrakło w doktrynie licznych opracowań monograficznych odnoszących się do poszczególnych dziedzin tejże regulacji. Stanowiły one pożyteczne źródło dla upowszechnienia odnośnych nowych norm kanonicznych, które należało aplikować we wszystkich obszarach życia kościelnego.

Gdy chodzi o Księgę I KPK - Normae generales, to znaczące opracowanie w postaci obszernego komentarza do tej materii kodeksowej wyszło spod pióra wybitnego profesora Katolickiego Uniwersytetu Lubelskiego (w latach 1920-1935), G. Michielsa (+1965), kapucyna belgijskiego, absolwenta Papieskiego Uniwersytetu Gregoriańskiego, późniejszego profesora Uniwersytetu w Québecu oraz Papieskiego Instytutu Obojga Praw w Rzymie ${ }^{17}$. To dwutomowe dzieło, wydane

\footnotetext{
${ }^{16}$ M. Wyszyński, Co katolik powinien wiedzieć o prawie kanonicznym, Katowice 1939.

${ }^{17}$ Cf. M. Myrcha, Śp. Ojciec Gommarus a Booischot Michiels, Prawo Kanoniczne 9(1966) nr 3-4, s. 429-444; P. PAєкA, Śp. o. prof. dr Gommar Michiels, Zeszyty
} 
w języku łacińskim: „Normae generales iuris canonici. Commentarius libri I Codicis Iuris Canonici" wydane w 1929 roku (wznowione 20 lat później) niewiele straciło na wartości także współcześnie ${ }^{18}$.

$\mathrm{Na}$ temat instytucji konkordatu interesujące opracowanie: „Konkordat. Studium prawne" zaprezentował J. Wiślicki (+1944), profesor Katolickiego Uniwersytetu Lubelskiego ${ }^{19}$. Tenże autor opublikował również komentarz do kann. 25-30 (zwyczaj) ${ }^{20}$. Natomiast I. Grabowski jest autorem opracowania na temat precedencji w ustawodawstwie kościelnym (kan. 106) ${ }^{21}$.

Kilka cennych prac zostało poświęconych kwestiom uregulowanym w Księdze II KPK - Depersonis. Przede wszystkim chodzi tutaj o znaczącą, dwutomową pracę G. Michielsa: „Principia generalia de personis in Ecclesia. Commentarius Libri primi Codicis Iuris Canonici. Canones praeliminares 87-106" z 1932 roku (wydanie wznowiono w 1955 roku $)^{22}$.

Poza tym należy wymienić dwie prace: H. Insadowskiego (+1946), profesora prawa kanonicznego i prawa rzymskiego na Katolickim Uniwersytecie Lubelskim: „Ustrój prawny Kościoła katolickiego”23 oraz „Osoba prawna. Studium prawno-historyczne”24, a następnie

Naukowe KUL 9(1966), z. 3, s. 94-98; A. Petrani, Wydział Prawa Kanonicznego Katolickiego Uniwersytetu Lubelskiego i jego działalność naukowa w czasie ostatniego dwudziestolecia, Zeszyty Naukowe KUL 8(1965), z. 3, s. 27-32; A. Petrani, Wydział Prawa Kanonicznego Katolickiego Uniwersytetu Lubelskiego i jego działalność dydaktyczno-naukowa w ciągu ubiegłego pięćdziesięciolecia, Roczniki Teologiczno-Kanonicze 15(1968), z. 5, s. 14-15.

${ }^{18}$ G. Michiels, Normae generales iuris canonici. Commentarius libri I Codicis Iuris Canonici, t. 1-2, Lublin 1929 (wyd. 2: Romae-Tornaci 1949).

${ }^{19}$ J. WiśLICKI, Konkordat. Studium prawne, Lublin 1926.

${ }^{20}$ J. WiśLICKI, Zwyczaj w prawie kanonicznym, Lublin 1926.

${ }^{21}$ I. GR ABOwski, Zasady pierwszeństwa w ustawodawstwie kościelnym, Warszawa 1933.

${ }^{22}$ G. Michiels, Principia generalia de personis in Ecclesia. Commentarius Libri primi Codicis Iuris Canonici. Canones praeliminares 87-106, t. 1-2, Romae-Tornaci 1932 (wyd. 2: Romae-Tornaci 1955).

${ }^{23}$ H. InsAdowski, Ustrój prawny Kościoła katolickiego, Lublin 1926.

${ }^{24}$ Tenże, Osoba prawna. Studium prawno-historyczne, Lublin 1927. 
prace: J. Wiślickiego (+1944), profesora Katolickiego Uniwersytetu Lubelskiego: „Prawa świeckich w Kościele katolickim”25 i P. Pałki (+ 1992), profesora Katolickiego Uniwersytetu Lubelskiego: „Uzupełnienie jurysdykcji w prawie kanonicznym"26.

Najwięcej publikacji powstało w obszarze Księgi III KPK - De rebus. Dominuje tutaj prawo małżeńskie, które znajduje swoją aplikację zarówno w sądownictwie i administracji kościelnej, jak i w praktyce duszpasterskiej. Pierwszy podręcznik kodeksowego prawa małżeńskiego, o nachyleniu praktycznym, z przeznaczeniem przede wszystkim dla duszpasterzy („Prawo kanoniczne małżeńskie”), wyszedł w 1919 roku spod pióra J. Pyci (+1942), profesora w Seminarium Duchownym w Kielcach, i miał dwa kolejne wydania ${ }^{27}$. Bardziej ambitnym podręcznikiem jest dzieło W. Szmyda (+1939), moralisty, profesora Uniwersytetu Jagiellońskiego, wykładającego prawo kanoniczne („Praktyczny podręcznik prawa małżeńskiego”) ${ }^{28}$. Autorami kolejnych komentarzy byli: B. Wilamowski (+1952), profesor Uniwersytetu Wileńskiego, a następnie Uniwersytetu Łódzkiego („Prawo małżeńskie Kościoła rzymsko-katolickiego” ${ }^{29}$ oraz profesorowie Katolickiego Uniwersytetu Lubelskiego („Małżeństwo w świetle nauki katolickiej" - praca zbiorowa $)^{30}$. Obydwa te opracowania nie wyczerpywały jednak wszystkich zagadnień uregulowanych w $\mathrm{KPK}^{31}$.

${ }^{25}$ J. Wiślicki, Prawa świeckich w Kościele katolickim, Lublin 1939.

${ }^{26}$ P. PAŁKA, Uzupetnienie jurysdykcji w prawie kanonicznym, Lublin 1936.

${ }^{27}$ J. Pycia, Prawo kanoniczne małżeńskie, Kielce 1919 (wyd. 2: Kielce 1920; wyd. 3, poprawione i uzupełnione): Kielce 1922); Zob. także W. Góralski, Polskojęzyczne podręczniki i komentarze do skodyfikowanego prawa małżéskiego Kościoła Łacińskiego i Kościołów Wschodnich, Ius Matrimoniale 27(2016), nr 1, s. 9-10.

${ }^{28}$ W. Szmyd, Praktyczny podręcznik prawa małżeńskiego, Kraków 1929; Zob. także W. Góralski, Polskojęzyczne podręczniki i komentarze, art. cyt., s. 13-15.

${ }^{29}$ B. Wila mowski, Prawo małżeńskie Kościoła rzymsko-katolickiego, Wilno 1928.

${ }^{30}$ Małżeństwo w świetle nauki katolickiej. Praca zbiorowa profesorów Uniwersytetu Lubelskiego, Lublin 1928.

${ }^{31}$ Cf. S. Biskupski, Prawo małżńskie Kościoła rzymskokatolickiego, Warszawa 1956, s. 5; W. Góralski, Polskojęzyczne podręczniki i komentarze, art. cyt., s. 13. 
Pozostałe prace zostały poświęcone określonym kwestiom małżeńskim. Ich autorami są: H. Insadowski („Separacja małżeńska”) ${ }^{32}$, I. Grabowski („Kompetencje władz w sprawach małżeńskich”33 oraz „Zagadnienie małżeństwa”) ${ }^{34}$, P. Kałwa (+1974), profesor Katolickiego Uniwersytetu Lubelskiego („Skutki adopcji cywilnej w kościelnym prawie małżeńskim") ${ }^{35}$, P. Bober (+1955), profesor Katolickiego Uniwersytetu Lubelskiego, a następnie Akademii Teologii Katolickiej w Warszawie („Pojęcie tajnej przeszkody małżeńskiej w prawie kanonicznym") ${ }^{36}$, T. Bensch (+1958), profesor Katolickiego Uniwersytetu Lubelskiego („Wpływ chorób umysłowych na ważność umowy małżeńskiej w prawie kanonicznym”) 37, F. Olszewski (+1992), asystent na Wydziale Teologicznym Uniwersytetu Warszawskiego („Głoszenie zapowiedzi małżeńskich w prawie kanonicznym”) ${ }^{38}$, M. Wyszyński („Czy metus indirecte incussus może unieważnić małżeństwo”) ${ }^{39}$.

W obszarze innych zagadnień prawa rzeczowego należy wskazać następujące opracowania: J. Roth: „Upoważnienie zakonników do słuchania spowiedzi wiernych w swoim rozwoju historycznym" ${ }^{40}$,

\footnotetext{
${ }^{32}$ H. Insadowski, Separacja małżeńska, Lwów 1928.

${ }^{33}$ I. Gr AвOwsKi, Kompetencje władz w sprawach małżeńskich, Przegląd Katolicki 71(1933), s. 133-136, 149-151, 166-168, 181-184, 213-215, 230-237, 151-164, 271-179, 293 -295, 311-313, 373-377, 406-408, 421-424, 454-457.

${ }^{34}$ Tenże, Zagadnienie małżeństwa, Warszawa 1934.

${ }^{35}$ P. KAŁWA, Skutki adopcji cywilnej w kościelnym prawie małżeńskim, Lublin 1935.

${ }^{36}$ P. Bober, Pojęcie tajnej przeszkody małżeńskiej w prawie kanonicznym, Lublin 1935.

${ }^{37}$ T. BENSCH, Wpływ chorób umysłowych na ważność umowy małżeńskiej w prawie kanonicznym, Lublin 1936.

${ }^{38}$ F. Olszewski, Głoszenie zapowiedzi małżeńskich w prawie kanonicznym, Lublin 1936.

${ }^{39}$ M. Wyszyński, Czy „metus indirecte incussus” może unieważnić małżeństwo, Przegląd Teologiczny 11(1930), s. 60-76, 183-220 oraz (w jęz. łacińskim) Ius Pontificium 10(1930), s. 193-200, 11(1931), s. 42-51. 12(1932), s. 43-52, 122-127, 13(1933), s. $52-63$.

${ }^{40} \mathrm{~J}$. Rотн, Upoważnienie zakonników do słuchania spowiedzi wiernych $w$ swoim rozwoju historycznym, Pamiętnik Związku Zakładów Teologicznych w Polsce 8(1936), s. 206-220.
} 
H. Insadowski, „Kościelne prawo pogrzebowe”41, I. Grabowski: Bierzmowanie w ustawodawstwie kościelnym” ${ }^{2}$, M. Wyszyński: „Reguły de annali possessore i de triennali possessore a nowy Kodeks Prawa Kanonicznego"43, M. Wyszyński: „Jak doszło w prawie kanonicznym do zasiedzenia beneficjów” ${ }^{4}$, S. Czajka: „Przedawnienie w prawie kanonicznym”45, W. Szmyd: „Odpusty” ${ }^{46}$.

Odnośnie do Księgi IV KPK - De processibus przedstawiciele doktryny skupili swoją uwagę na różnych kwestiach procesowych. I. Grabowski jest autorem czterech opracowań: „Proces kanoniczny w nowym Kodeksie” ${ }^{47}$, „Adwokatura w ustawodawstwie kościelnym”48, „Notariusz w ustawodawstwie kościelnym”49 i „Procedura kanoniczna w sprawach małżeńskich” ${ }^{0}$. Trzy prace wyszły spod pióra J.W. Krzemienieckiego (+1956), profesora Uniwersytetu Jagiellońskiego: „Procedura administracyjna w Kodeksie Prawa Kanonicznego”51, „Główne warunki ważności kanonicznego procesu administracyjnego" 52 i „Z kanonicznej procedury administracyjnej" ${ }^{53}$. Ponadto prace z prawa procesowego opubliko-

${ }^{41} \mathrm{H}$. InsAdowski, Kościelne prawo pogrzebowe, Włocławek 1930.

${ }^{42}$ I. Grabowski, Bierzmowanie w ustawodawstwie kościelnym, Ateneum Kapłańskie 49(1948), s. 433-458; 50(1949), s. 32-42, 137-145.

${ }^{43}$ M. Wyszyński, Reguły „de annali possessore” $i$,,de triennali possessore” a nowy Kodeks Prawa Kanonicznego, Przegląd Teologiczny 5(1924), s. 247-263 i 6(1925), s. 116-118.

${ }^{44}$ TenżE, Jak doszło $w$ prawie kanonicznym do zasiedzenia beneficjów, w: Księga pamiątkowa ku czci Leona Pinińskiego, t. 2, Lwów 1936, s. 42-60.

${ }^{45}$ S. Czajka, Przedawnienie w prawie kanonicznym, Lublin 1934.

${ }^{46}$ W. Szmyd, Odpusty, Kraków 1930.

${ }^{47}$ I. Grabowski, Proces kanoniczny w nowym Kodeksie, Lwów 1918.

${ }^{48}$ TenżE, Adwokatura w ustawodawstwie kościelnym, Włocławek 1935.

${ }^{49}$ TenżE, Notariusz w ustawodawstwie kościelnym, Collectanea Theologica 16(1936), s. 585-636.

50 Tenże, Procedura kanoniczna w sprawach małżéskich, Warszawa 1938.

${ }^{51}$ J.W. Krzemieniecki, Procedura administracyjna $w$ Kodeksie Prawa Kanonicznego, Kraków 1925.

${ }^{52}$ TenżE, Główne warunki ważności kanonicznego procesu administracyjnego, Kraków 1930.

${ }^{53}$ TenżE, Z kanonicznej procedury administracyjnej, Kraków 1930. 
wali: J. Roth: „Zarys procesu małżeńskiego” ${ }^{44}$, S. Biskupski: „Zagadnienie obrońcy węzła" 55 oraz M. Myrcha (+1996), profesor Akademii Teologii Katolickiej w Warszawie: „Dowód ze świadków w procesie kanonicznym" 56 .

Gdy chodzi wreszcie o Księgę V KPK - De delictis et penis, to przede wszystkim wymienić trzeba dzieło G. Michielsa „De delictis et poenis. Commentarius libri V Codicis Iuris Canonici, t. 1: De delictis. Canones 2195-2213" ${ }^{57}$. Poza tym prace z prawa karnego ogłosili: I Grabowski: „Karne prawo kościelne w nowym Kodeksie”58, J.W. Krzemieniecki: „Przestępstwo apostazji, herezji i schizmy w Kodeksie Prawa Kanonicznego. Kanon 2314 i jego praktyczne zastosowanie"59, W. Szmyd: „Kary kościelne” ${ }^{20}$ L. Halban: „Zwiększenie odpowiedzialności karnej w prawie kanonicznym z powodu wyższej społecznej godności winowajcy" ${ }^{61}$ i P. Kurczyński (+1942), promotor sprawiedliwości w Sądzie Biskupim Częstochowskim: „De natura et observantia poenarum latae sententiae"62.

W recepcji norm KPK z zakresu prawa zakonnego (Księga II, część II: De religiosis (cann. 487-681) dużą pomocą okazało się tłumaczenie kanonów tego segmentu kodeksowego dokonane przez jezuitę

\footnotetext{
${ }^{54}$ J. Rотн, Zarys procesu małżéskiego, Kraków 1920.

${ }^{55}$ S. Biskupski, Zagadnienie obrońcy węzła, Włocławek 1939.

${ }^{56}$ M. Myrcha, Dowód ze świadków w procesie kanonicznym, Lublin 1936.

${ }^{57}$ G. Michiels, De delictis et poenis. Commentarius libri V Codicis Iuris Canonici, t. 1: De delictis. Canones 2195-2213, Romae-Tornaci 1934 (wyd. 2: Romae-Tornaci 1949).

${ }^{58}$ I. Grabowski, Karne prawo kościelne w nowym Kodeksie, Lwów 1918.

${ }^{59}$ J.W. Krzemieniecki, Przestępstwo apostazji, herezji i schizmy w Kodeksie Prawa Kanonicznego. Kanon 2314 i jego praktyczne zastosowanie, Ateneum Kapłańskie 40(1937), s. 34-45, 133-147; J. BAR, Śp. ks. prof. dr Jan Władysław Krzemieniecki, Polonia Sacra 8(1956), s. 217-222.

${ }^{60}$ W. Szmyd, Kary kościelne, Kraków 1929.

${ }^{61}$ L. HALBAN, Zwiększenie odpowiedzialności karnej w prawie kanonicznym z powodu wyższej społecznej godności winowajcy, Przegląd Teologiczny 9(1928), s. 1-21.

${ }^{62}$ P. KurCZYŃski, De natura et observantia poenarum latae sententiae, Lublin 1938.
} 
J. Rotha (wespół z W. Szmydem, również jezuitą) w 1918 roku ${ }^{63}$. W ten sposób wymienieni kanoniści starali się udostępnić normy nowego prawa zakonnego osobom mającym trudności ze rozumieniem tekstu oryginalnego. Tym bardziej, że w tym okresie podejmowano liczne prace nad dostosowywaniem konstytucji zakonnych do nowego prawa oraz nad układaniem nowych ${ }^{64}$.

Co się tyczy czasopism, w których kanoniści publikowali swoje prace, to należy wymienić przede wszystkim: „Collectanea Theologica”, „Ateneum Kapłańskie”, „Kwartalnik Teologiczny Wileński”, „Polonia Sacra”, „Nova Polonia Sacra. Czasopismo poświęcone badaniu historii Kościoła, prawa kanonicznego i literatury teologicznej w Polsce”, „Przegląd Teologiczny”, „Gazeta Kościelna. Pismo poświecone sprawom kościelnym i społecznym”" Na periodyki poświęcone specjalnie prawu kanonicznemu przyszło czekać kilka dziesiątków lat.

Długotrwały, podstawowy etap w procesie przyswajania sobie przez Kościół w Polsce KPK wyrażał się zatem w rozwoju doktryny prawa kanonicznego skupionej na prezentowaniu, wyjaśnianiu i komentowaniu nowych regulacji. Dość liczne publikacje, odnoszące się do poszczególnych ksiąg kodeksowych, niewątpliwie spełniały ważną rolę nie tylko w płaszczyźnie stricte naukowej, lecz także jako właściwe narzędzia służące biskupom i innym duszpasterzom oraz licznym instytucjom kościelnym w wypełnianiu powierzonej im misji. Należy dodać, że publikacje te przyczyniły się w znacznej mierze do upowszechnienia jednolitości ustawodawstwa w kraju w zakresie prawa małżeńskiego po latach niewoli narodowej, kiedy to w poszczególnych zaborach (rosyjskim, austriackim i pruskim) obowiązywały różne małżeńskie systemy prawne.

\footnotetext{
${ }^{63}$ J. Roth, Prawo zakonne. Przepisy Kodeksu Prawa Kanonicznego, Kraków 1918 (wyd. 2: Kraków 1919).

${ }^{64}$ M. Żurowski, Jan Roth-profesor-kanonista, Warszawa 1971, s. 92-93.

${ }^{65}$ Zob. P. Hemperek, Kanonistyka polska, art. cyt., s. 63.
} 


\section{W nauczaniu}

Wraz z rozwojem doktryny kanonistycznej szło w parze nauczanie prawa kanonicznego. Te dwa czynniki, ściśle ze sobą powiązane, stwarzały odpowiednie warunki do upowszechniania znajomości, w szczególności wśród duchownych i kandydatów do kapłaństwa, KPK.

Gdy chodzi o uczelnie, w których wykładano ius canonicum, to Polska miała bogate tradycje sięgające roku 1364, kiedy to doszło do utworzenia Uniwersytetu Krakowskiego, gdzie na wydziale prawa, obok pięciu katedr prawa rzymskiego, istniały trzy katedry prawa kanonicznego (Dekretu Gracjana, Dekretałów Grzegorza IX oraz Liber Sextus i Klementyn); w 1580 roku było ich już siedem (Reguł prawa, Instytucji prawa kanonicznego, „Casuum conscientiae”, Świętych kanonów, Procesu, „Antiquorum iurium” oraz Prawa rzymskiego), a profesorami byli niejednokrotnie absolwenci włoskich wydziałów prawa $^{66}$. W kolejnych stuleciach powstawały nowe ośrodki akademickie, w których uprawiano prawo kanoniczne ${ }^{67}$.

W chwili odzyskania przez Polskę niepodległości w 1918 roku, na terenie odrodzonego państwa istniały trzy uniwersytety: Uniwersytet Jagielloński w Krakowie, Uniwersytet Lwowski i Uniwersytet Warszawski. Na uczelniach tych była uprawiana, i to na wysokim poziomie, kanonistyka (na wydziałach teologicznych i na wydziałach prawa), przy czym na Uniwersytecie Warszawskim sekcja prawa kanonicznego powstała na wydziale teologicznym dwa lata później (mając uprawnienie do nadawania stopni doktorskich). W 1918 roku

${ }^{66}$ T. PAwluk, Wprowadzenie do studiów kanonistycznych, Warszawa 1979, s. 27-28; Zob. także A. Stanowski, Spis wykładowców 1918-1939, Wydział Prawa Kanonicznego [KUL], w: Księga jubileuszowa 50-lecia Katolickiego Uniwersytetu Lubelskiego, Lublin 1969, s. 105-118; J. SAwICKI, Die Entwicklung der Kirchenrechtswissenschaft i Polen 1918-1957, Österreichisches Archiv fùr Kirchenrecht 9(1958), s. 243-269. T. PAwluk, Z zagadnień kanonistyki polskiej, Prawo Kanoniczne 19(1976) nr 3-4, s. 153-230.

${ }^{67}$ Zob. T. Pawluk, Wprowadzenie do studiów kanonistycznych, dz. cyt., s. 28-32; W. GóRAlski, Wydział teologiczny na uniwersytecie. Aspekt historyczno-prawny, Studia Nauk Teologicznych 3(2008), s. 23-47. 
utworzono - z inicjatywy ostatniego rektora zniesionej wówczas Akademii Duchownej w Petersburgu - Uniwersytet w Lublinie (od 1920 roku Katolicki Uniwersytet Lubelski), gdzie obok Wydziału Teologicznego powstał Wydział Prawa Kanonicznego i Nauk Moralnych (od 1923 roku Wydział Prawa Kanonicznego, jako pierwszy w Polsce). Na trzech sekcjach tej jednostki (prawno-społeczna, prawno-historyczna i prawno-moralna) prawo kanoniczne stanowiło główny przedmiot. Ponadto na Wydziale Prawa i Nauk Społeczno-Ekonomicznych istniała katedra prawa kanonicznego ${ }^{68}$.

W 1919 roku przywrócono Uniwersytet Wileński (z wydziałem teologicznym, na którym funkcjonowała katedra prawa kanonicznego), a także utworzono Uniwersytet Poznański (bez wydziału teologicznego); prawo kanoniczne było jednak wykładane na Wydziale Prawa ${ }^{69}$.

Studiujący prawo kanoniczne na wymienionych jednostkach organizacyjnych - pod kierunkiem niejednokrotnie wybitnych kanonistów, których dorobek naukowy został ukazany wyżej - zapoznawali się bliżej z całokształtem norm prawnych KPK. Wykłady z zakresu poszczególnych segmentów tego prawa prowadzone były zgodnie z regułami, które określiła Kongregacja Seminariów i Uniwersytetów w Dekrecie z 7 sierpnia 1917 roku. Dokument ten wymagał, by nauczający ius canonicum dokonywali w wykładzie nie tylko pewnej syntezy, lecz także dokładnej analizy (egzegezy) poszczególnych kanonów kodeksowych. Zobowiązywał również do ścisłego trzymania się w wykładzie porządku materii przyjętego w Kodeksie, nawet w przypadku posługiwania się przez wykładowcę podręcznikiem. Polecał również, by wykład danej instytucji prawnej był poprzedzony zwięzłym objaśnieniem jej genezy i historii, a jako podstawowe źródło i zarazem podręcznik wskazano w Dekrecie Kodeks ${ }^{70}$. Od 1931 roku

\footnotetext{
${ }^{68}$ A. Petrani, Wydział Prawa Kanonicznego Katolickiego Uniwersytetu Lubelskiego i jego działalność naukowa w czasie ostatniego dwudziestolecia, Zeszyty Naukowe KUL 8(1965), z. 3, s. 11-18; W. Góralski, La canonistica polacca oggi, Ius Ecclesiae 24(2012), nr 2, s. 349-358.

${ }^{69}$ T. Pawluk, Wprowadzenie do studiów kanonistycznych, dz. cyt., s. 44.

${ }^{70} \mathrm{~S}$. Congregatio Seminariorum Et Universitatum, Decretum de novo iuris canonici Codice in scholis proponendo (07.08.1917), AAS 9(1917), s. 439; W. WójCıк,
} 
w wykładach prawa kanonicznego stosowano się również do przepisów Konstytucji apostolskiej Piusa XI Deus scientiarum Dominus z 24 maja 1931 roku $^{71}$ oraz do Ordinationes Kongregacji Seminariów i Uniwersytetów z 12 czerwca 1931 roku $^{72}$.

Ta sama Kongregacja wydała 31 października 1918 roku Dekret regulujący kwestię egzaminów przewidzianych do uzyskania stopni naukowych z prawa kanonicznego na uniwersytetach i wydziałach podległych tej dykasterii ${ }^{73}$. Określone w tym dokumencie wymagania zostały powtórzone w konstytucji apostolskiej Deus scientiarum Dominus, eksponując Kodeks jako podstawowe źródło-podręcznik ${ }^{74}$

Prawo kanoniczne było przedmiotem wykładów i studiów również w seminariach duchownych, które stanowiły znaczący czynnik w upowszechnianiu wśród przyszłych duchownych znajomości KPK. Nauczanie wymienionego przedmiotu w seminariach w Polsce było przedmiotem obrad Związku Zakładów Teologicznych (Sekcja Prawno-Kanoniczna), poczynając od pierwszego zjazdu, który odbył się w 1921 roku we Włocławku a kończąc na ósmym, który miał miejsce w 1936 roku w Częstochowie. Podczas tych spotkań zwracano uwagę m.in. na potrzebę przygotowania odpowiedniej kadry wykładowców prawa kanonicznego. Debatowano również na temat programu studiów seminaryjnych w zakresie ius canonicum, podręczników do tej dyscypliny, koordynacji między wykładami

Wytyczne w nauczaniu prawa kanonicznego kandydatów do kapłaństwa, Roczniki Teologiczno-Kanoniczne 23(1976), s. 5 i 11-13.

${ }^{71}$ PIUs XI, Constitutio apostolica „Deus scientiarum Dominus” (24.05.1931), AAS 23(1931), s. 241-262.

72 S. Congregatio Seminariorum Et Universitatum, Ordinationes (12.06.1931), AAS 23(1931), s. 263-264.

${ }^{73}$ S. Congregatio Seminariorum Et Universitatum, Decretum de experimentis ad gradus in iure canonico assequendos, AAS 11(1919), s. 19.

${ }^{74}$ Zob. J. GręźLIKowski, Dyskusje nad nauczaniem prawa kanonicznego w seminariach duchownych w Polsce okresu międzywojennego, w: Finis legis Christus. Księga pamiątkowa dedykowana Księdzu Profesorowi Wojciechowi Góralskiemu z okazji siedemdziesiątej rocznicy urodzin, red. J. Wroceński, J. Krajczyński, Warszawa 2009, s. 425-426; W. GórAlski, Nauczanie prawa kanonicznego w Seminarium Duchownym w Płocku (1710-2010), Studia Płockie 38(2010), s. 59-60. 
z prawa kanonicznego a zajęciami z innych przedmiotów (m.in. z teologii moralnej), a także pożytku prowadzenia seminariów naukowych z prawa kanonicznego. Podkreślano jednocześnie rolę Kodeksu jako rodzaju podręcznika, natomiast podręczniki-komentarze do KPK zalecano jedynie jako pomoc w wykładzie norm kodeksowych, co było zgodne z dyrektywą powołanego wyże Dekretu Kongregacji ${ }^{75}$.

Gdy chodzi o rolę Kodeksu jako wiodącego źródła w nauczaniu prawa kanonicznego w seminariach duchownych, to szerzej dyskutowano nad tym zagadnieniem podczas zjazdu Sekcji Prawo-Kanonicznej w Lublinie w 1923 roku. Mając na uwadze powołany wyżej Dekret Kongregacji Seminariów i Uniwersytetów z 7 sierpnia 1917 roku, referent oraz uczestnicy zjazdu postulowali, by „Kodeks, jako księga całej umiejętności” i jako pierwszorzędna podstawa wykładu, stanowił w rekach każdego słuchacza „główny podręcznik”, inne zaś dzieła mogą mieć charakter jedynie pomocniczy ${ }^{76}$.

Podczas zjazdu w Łomży w 1925 roku wysunięto postulat wprowadzenia podręcznika prawa kanonicznego w seminariach duchownych, jako komentarza do Kodeksu ${ }^{77}$, jednak podczas obrad w Kielcach (w 1927 roku) uznano, że tego rodzaju podręcznik można jedynie zalecać (nie może „przesłonić” Kodeksu); sugerowano wówczas

${ }^{75}$ J. GręźLIKowski, Dyskusje nad nauczaniem prawa kanonicznego, art. cyt., s. 427-428.

${ }^{76}$ Tamże, s. 431; Jak stwierdza W. Wójcik, w seminarium sandomierskim sesja profesorów zadecydowała 26 sierpnia 1918 roku, że wykładowca prawa kanonicznego powinien poprzestać na wyjaśnianiu tekstu autentycznego KPK, co w praktyce nastręczało wiele trudności, gdyż wykładowca wydał drukiem swoje skrypty z prawa osobowego i rzeczowego. Opracowania te, zawierające „luźne” tłumaczenie odnośnych kanonów Kodeksu, służyły seminarzystom przez wiele lat. Zastąpił je dopiero podręcznik F. Bączkowicza („Prawo kanoniczne”, Kraków 1923), który - do 1939 roku - wszyscy seminarzyści posiadali. „Podczas wykładów podkreślali oni ważniejsze zdania oraz dodawali zapiski marginesowe z wykładów profesora”. W. Wójcıк, Nauczanie prawa kanonicznego w Seminarium Duchownym w Sandomierzu, Prawo Kanoniczne 15(1972) nr 3-4. s. 110.

77 Tamże, s. 424. 
korzystanie z dzieła F.M. Cappello „De matrimonio” (jako t. 5 pracy „Tractatus canonico-moralis de sacramentis” ${ }^{78}$.

Sprawa przygotowania umysłowego seminarzystów oraz roli wykładowców prawa kanonicznego w seminariach duchownych w formacji kanonistycznej przyszłych duchownych stała się szczególnym przedmiotem obrad zjazdu Sekcji Prawno-Kanonicznej Związku Zakładów Teologicznych, który odbył się w 1929 roku w Łodzi. Referat I. Grabowskiego „Studium prawa kanonicznego” dał asumpt do dyskusji nad formacją przyszłych duchownych w zakresie prawa kanonicznego w seminariach duchownych oraz nad jego znaczeniem w życiu wspólnoty chrześcijańskiej. Autor referatu postulował m.in. potrzebę nawiązywania w wykładach prawa kanonicznego do takich dyscyplin, jak historia prawa, prawo rzymskie, prawo starogermańskie i prawo polskie ${ }^{79}$. Uczestnicy debaty z kolei zwrócili uwagę (mając zapewne na uwadze kan. $1366 \$ 1 \mathrm{KPK}$ ) na potrzebę odpowiedniego przygotowania profesorów prawa kanonicznego dla seminariów duchownych oraz prowadzenia przez nich konwersatoriów w celu praktycznego przygotowania seminarzystów do rozwiązywania różnych przypadków prawnych ${ }^{80}$. Podkreślono ponadto potrzebę prywatnej (indywidualnej) lektury Kodeksu przez seminarzystów orz prowadzenia wykładów prawa kanonicznego w języku łacińskim ${ }^{81}$.

$\mathrm{Na}$ uwagę zasługuje również tematyka poruszana podczas analogicznego zjazdu z 1936 roku, który odbył się w Częstochowie, jako ostatni w interesującym nas okresie. Zwrócono wówczas uwagę na potrzebę prowadzenia pracy naukowej przez wykładowców prawa kanonicznego w seminariach duchownych, oceniono bowiem, że ich zaangażowanie w tę sferę życia kościelnego jest niewystarczające, gównie $\mathrm{z}$ uwagi na wykonywanie przez nich innych zadań, przede

\footnotetext{
78 Tamże, s. 434.

${ }^{79}$ I. Grabowski, Studium prawa kanonicznego, w: Pamiętnik piątego zjazdu w Łodzi 3 IV-5 IV 1929, Kielce 1929, s. 204-222.

${ }^{80}$ Tamże, s. 222-223.

${ }^{81}$ J. GręźLIKowski, Dyskusje nad nauczaniem prawa kanonicznego, art. cyt., s. 432 .
} 
wszystkim w kuriach biskupich i sądach kościelnych ${ }^{82}$. Tymczasem, stwierdzono, aktywność piśmiennicza kanonistów może mieć znaczny wpływ m.in. na dziedzinę duszpasterst wa ${ }^{83}$. Do publikowania prac kanonistycznych zachęcał wykładowców seminaryjnych także wcześniejszy (w 1927 roku) zjazd w Kielcach ${ }^{84}$.

W nauczaniu prawa kanonicznego, tak uniwersyteckim, jak i seminaryjnym, KPK Pio-Benedyktyński znajdował więc swój wartki strumień, przez który ius novissimum docierało do szerokich rzesz przyszłych kanonistów oraz przyszłych duszpasterzy. Ci pierwsi, zgłębiając regulacje kodeksowe, przygotowywali się do podjęcia posług w zakresie nauczania oraz do pełnienia szczególnych zadań w administracji kościelnej i w sądownictwie kościelnym, dla drugich zaś znajomość prawa kanonicznego miała okazać się nieodzowna w przyszłej posłudze duszpasterskiej wykonywanej w parafiach. Podczas gdy dla studiujących prawo kanoniczne w uniwersytetach, niejednokrotnie rzymskich, wyznacznikiem były programy studiów nakreślone stosownie do norm Stolicy Apostolskiej, to dla adeptów do kapłaństwa w seminariach duchownych znaczące były również dyrektywy podejmowane podczas zjazdów Związku Zakładów Teologicznych (Sekcja Prawno-Kanoniczna).

\section{W Kościołach partykularnych}

Moment promulgacji KPK od samego początku mobilizował biskupów ordynariuszy do podejmowania działań zmierzających do upowszechnienia przepisów tej kolekcji i wdrażania ich w życie diecezji. Działania te szły w dwóch podstawowych kierunkach: doraźnego informowania i instruowania duchowieństwa w kwestii

\footnotetext{
${ }^{82}$ Kan. $1366 \$ 3$ KPK nie wymagał jednak, by wykłady z prawa kanonicznego w seminariach duchownych prowadził odrębny profesor, co sprawiało, że niejednokrotnie prawo kanoniczne wykładał profesor prowadzący wykłady także z innego przedmiotu.

${ }^{83}$ J. GręźLikowski, Dyskusje nad nauczaniem prawa kanonicznego, art. cyt., S. 429.

${ }^{84}$ Tamże, s. 438.
} 
nowego Kodeksu oraz podejmowania próby skodyfikowania prawa diecezjalnego na drodze synodu.

Jakkolwiek biskupom polskim od początku przyświecała idea przeprowadzenia we własnych diecezjach synodów, które pozwoliłyby dostosować prawo partykularne do ustawodawstwa kodeksowego, co wymagałoby odpowiedniego przygotowania, to jednak uznali, że pierwszym krokiem, niejako wstępnym na tej drodze, powinno być urzędowe informowanie swoich kapłanów o promulgacji przez Benedykta XV KPK, a także o wprowadzonych przezeń zmianach $\mathrm{w}$ stosunku do prawa powszechnego.

Troskliwy biskup diecezji płockiej Antoni Julian Nowowiejski ${ }^{85}$ już 26 września 1917 roku, a więc cztery miesiące po ogłoszeniu Kodeksu, zaprezentował (ogólnie) ten zbiór prawa podczas konferencji dziekanów. Informując ich o tym wydarzeniu, wydał jednocześnie stosowne polecenie: „Każdy kapłan musi nabyć Kodeks, gdy tylko stanie się to możliwe, i przestudiować go pilnie, aby wiedział, co go obowiązuje" ${ }^{86}$. Zaznaczył przy tym, że w zbiorze tym jest wiele dyspozycji, na które należy zwrócić uwagę, następnie podał istotną treść niektórych kanonów (z różnych ksiąg Kodeksu) ${ }^{87}$.

Z kolei 19 maja 1918 roku rządca diecezji przypomniał duchowieństwu o wejściu w życie KPK zaznaczając, że ponieważ dotąd nie można nabyć Kodeksu, zwraca uwagę na kan. 470 (prowadzenie ksiąg

\footnotetext{
${ }^{85}$ Antoni Julian Nowowiejski (1858-1941), biskup płocki w latach 1908-1941 (w 1930 wyróżniony przez Piusa XI tytułem arcybiskupa), autor licznych dzieł liturgicznych, jeden $z$ najwybitniejszych rządców diecezji na przestrzeni stuleci (diecezja została utworzona w 1075 roku), poniósł śmierć męczeńską w obozie niemieckim w Działdowie. W 1999 Jan Paweł II ogłosił go błogosławionym (wraz z 107 innymi ofiarami nazizmu hitlerowskiego).

${ }^{86}$ Sprawozdanie z konferencji dziekanów (26.09.1917), Miesięcznik Pasterski Płocki 12(1917), nr 10, s. 271.

${ }^{87}$ Chodzi o kanony: 44, 84, 85, 356, 409, 419, 45-450, 463, 466, 470,490, 764, 768, $797,804,859,910,1011,1025,1076,1077,1078,1108,1176,1245,1250,1251,1252,1253$, $1254,1262,1263,1266,1274,1305,1410,1427,1503,1504,1505,1515,1516,1518-1529$, 1532. Tamże, s. 254-257; Zob. także Miesięcznik Pasterski Płocki 13(1918), nr 2, s. 37-38.
} 
parafialnych i dokonywanie adnotacji w księdze ochrzczonych) oraz na kann. 97, 768, 798, 1079 i $1108^{88}$.

W tym samym czasie biskup Nowowiejski apelował do księży: „Po otrzymaniu Kodeksu wszystkim trzeba będzie go pilnie studiować, aby prawo kościelne jak najściślej było zachowane dla pożytku naszego duchowego i dla zbawienia wiernych" ${ }^{39}$.

Niewątpliwie z sugestii ordynariusza płockiego, Aleksander Pęski ${ }^{90}$, doktor prawa kanonicznego, wykładowca tej dyscypliny w płockim seminarium duchowym, wygłosił podczas konferencji dziekanów kilka referatów na temat wybranych kwestii uregulowanych w KPK (niektóre z nich opublikował w 1918 i 1919 roku w diecezjalnym organie urzędowym) ${ }^{91}$.

Gdy wciąż trwał okres zapoznawania się z KPK, który został wydany w Rzymie i który należało nabyć, w „Liście do kapłanów o potrzebie i rodzajach formacji stałej" z 4 kwietnia 1922 roku rządca diecezji stwierdził: „Kodeks prawa kanonicznego stanowi mądre przepisy (c. 129) dla nabycia nauki, zachowania jej i uzupełnienia"92.

\footnotetext{
${ }^{88}$ Rozporządzenia diecezjalne, Miesięcznik Pasterski Płocki 13(1918), nr 2, s. 100-102.

89 Tamże, s. 101.

${ }^{90}$ Zob. W. Góralski, Ks. Adam Pęski (1867-1930), Prawo Kanoniczne 15(1972) nr 3-4, s. 301-310.

${ }^{91}$ Zob. A. PĘSKI, Nowa kodyfikacja prawa kanonicznego, Miesięcznik Pasterski Płocki 13(1918), nr 5, s. 103-105; Różnice między rozporządzeniami nowego Kodeksu i dotąd istniejąca praktyka w sprawach małżeńskich /25.09.1918, tekst niepublikowany, informacja: Miesięcznik Pasterski Płocki 13(1918), nr 10, s. 200/; Zarząd majątkiem kościelnym według Kodeksu prawa kanonicznego, Miesięcznik Pasterski Płocki 14(1919), nr 2, s. 41-47 (przytoczono tutaj m.in. kann. 1518-1542, 1182-1186 i 1545-1551 w języku polskim); „Multiplex consanguinitas”, Miesięcznik Pasterski Płocki 14(1919), nr 3, s. 62-63; Sprawa zmniejszenia dni świątecznych. Rzecz z racji kan. 1247, Miesięcznik Pasterski Płocki 14(1919), nr 6, s. 95-97; Cenzury w ogólności i ekskomunika w szczególności według nowego Kodeksu prawa kanonicznego, Miesięcznik Pasterski Płocki 14(1919), nr 6, s. 57-59.

${ }^{92}$ A.J. Nowowiejski, List do kapłanów o potrzebie i rodzajach formacji stałej, w: Listy z Tumskiego Wzgórza, cz. II: Pozostałe Listy Pasterskie oraz Orędzia, Dekrety i Zarządzenia, a także fragmenty korespondencji Bł. Abp. Antoniego Juliana Nowowiejskiego z lat 1909-1940, zebrał T. Żebrowski, Red. W. Banasiak, H. Seweryniak, Płock 2008, s. 122.
} 
O zaangażowaniu biskupa Nowowiejskiego w dzieło recepcji KPK wymownie świadczy i to, że w niektórych swoich aktach prawnych powoływał się na kanony tej kodyfikacji ${ }^{93}$.

Za właściwą formę wprowadzania w życie diecezji postanowień KPK biskupi uznawali instytucję synodu diecezjalnego, mającą zresztą swoją bogatą tradycję, drastycznie przerwaną rozbiorami Polski w latach 1772-1795 i utratą niepodległości. W statutach synodalnych upatrywali skuteczny środek służący dostosowaniu norm prawa partykularnego do obowiązującego w danym okresie prawa powszechnego ${ }^{94}$.

W okresie międzywojennym (1918-1939) odbyły się synody w trzynastu archidiecezjach i diecezjach polskich: warszawskiej (1922), sandomierskiej (1023), podlaskiej (1923), krakowskiej (1923), kieleckiej (1927), łuckiej (1927), płockiej (1927 i 1938), tarnowskiej (1928 i 1938), lubelskiej (1928), chełmińskiej (1928), pińskiej (1929), lwowskiej (1930) i wileńskiej $(1931)^{95}$. Poza tym w 1936 roku odbył się synod plenarny (w Częstochowie).

Zwołując te zgromadzenia biskupi pragnęli nie tylko dostosować swoje skazane na niepamięć (ową przerwą) prawo partykularne do norm kodeksowych, lecz także dokonać programowej reformy zniszczonych lub mocno nadwątlonych struktur i instytucji diecezjalnych oraz odnowić życie religijne diecezji. Obydwa te cele szły zresztą ze sobą w parze.

Ustawodawcy synodalni budowali normy prawne z reguły wzorując się na kanonach kodeksowych, przy czym można tu dostrzec pewną tendencję popularyzatorską oraz podbudowę moralno-ascetyczną

\footnotetext{
${ }^{93}$ Zob. np. A.J. Nowowiejski, Rozporządzenie w sprawie spowiedzi wielkanocnej oraz warunków zachowania wstrzemięźliwości i postu (11.01.1918), w: Listy z Tumskiego Wzgórza, dz. cyt., s. 87-88.

${ }^{94}$ Zob. W. Wóıcıк, Ze studiów nad synodami polskimi, Lublin 1982, s. 201.

95 Tamże, s. 219-222; Siedem archidiecezji i diecezji (gnieźnieńsko-poznańska, włocławska, łódzka, łomżyńska, przemyska, częstochowska i katowicka) nie zdołało w tym okresie odbyć swoich synodów. Zob. W. GórALSKI, „Ecclesia semper reformanda”. W nurcie synodów polskich - wczoraj i dziś, w: Oddanie i wytrwałość. Recepcja II polskiego synodu plenarnego, red. W. Góralski, H. Sewerynikak, Warszawa 2004, s. 56.
} 
i nachylenie duszpasterskie. Duchowieństwo otrzymywało więc dostosowany do KPK, ale także do wielowiekowej tradycji rodzimej, obowiązujący zbiór prawa partykularnego.

Przykładem recepcji KPK poprzez ustawodawstwo synodalne może być synod płocki biskupa Antoniego Juliana Nowowiejskiego z 1927 roku, odbyty w dniach 20-22 kwietnia w bazylice katedralnej w Płocku, z błogosławieństwem Piusa XI ${ }^{96}$.

Już w krótkim Wprowadzeniu do statutów synodalnych (oznaczonym jako statut pierwszy) zaznaczono, że synod, stosownie do kan. $356 \$ 1$ KPK traktuje jedynie o sprawach, które odnoszą się do szczególnych potrzeb lub pożytku duchowieństwa i wiernych diecezji. Nadmieniono również, że KPK powinien być czytany i bardzo ściśle przestrzegany przez duchownych ${ }^{97}$.

Struktura 215 statutów synodalnych obejmuje cztery Księgi: I - Normy ogólne (statuty: 2-9), II - O osobach (statuty: 10-86), III - O rzeczach (statuty: 87-210), IV - O karach kościelnych (statuty: 211-212) oraz Przepisy końcowe (statuty: 213-215). Jakkolwiek tylko w dwudziestu statutach powołano odpowiedni kanon Kodeksu, to jednak de facto dyspozycje synodalne oparte są na normach tego zbioru. Zaletą statutów jest ich zwięzłość, a także to, iż nie powtarzają odnośnych kanonów kodeksowych, choć zawierają postanowienia sformułowane w ich duchu. Na podkreślenie zasługuje i to, że ustawodawca diecezjalny reguluje szereg dziedzin właściwych lokalnej tradycji kanonicznej, mając jednak na uwadze dbałość o ich zgodność $\mathrm{z}$ regulacjami $\mathrm{KPK}$.

Do statutów synodalnych ${ }^{98}$ ustawodawca dodał 14 załączników w postaci instrukcji, statutów stowarzyszeń katolickich czy wzorów protokołów niektórych czynności prawnych ${ }^{99}$.

\footnotetext{
${ }^{96}$ Constitutiones XL-mae Synodi Dioecesanae Plocensis Anno MCMXXVII diebus nempe 20, 21, 22 Aprilis ab Excellentissimo, Illustrissimo ac Reverendissimo Antonio Juliano Nowowiejski Episcopo Plocensi in Bssilica Cathedrali celebratae, Plociae 1927.

97 Tamże, s. 3.

${ }^{98}$ Tamże, s. 3-48.

99 Tamże, s. 51- 126.
} 
Pierwsze doświadczenia synodalne okresu międzywojennego wskazywały, że oprócz synodów diecezjalnych niezbędne jest przeprowadzenie synodu plenarnego (ogólnopolskiego), którego uchwały ujednoliciłyby - w znacznej mierze - reguły życia kościelnego, w zgodności z KPK. Czymś znamiennym jest, iż w fazie przygotowawczej do synodu, podczas debaty Komisji Nadzwyczajnej nad wnioskami przedstawionymi przez biskupów, trwającej w dniach 20-25 kwietnia 1934 roku, postanowiono kierować się określonymi wytycznymi, m.in., by „,nie powtarzać tego, co już było w Kodeksie; nie ścieśniać postanowień kodeksowych bez poważnej przyczyny; nie stwarzać prawa, które krępowałoby biskupów i stanowiło niepotrzebny ciężar dla duchowieństwa; nie postanawiać czegoś, co nie będzie wykonane, wprowadzić pełną decentralizację - <mieć przed oczyma potrzeby całej Rzeczypospolitej, pozostawiając zarządzeniom właściwych Ordynariuszów specjalne potrzeby i przeszkody> [...], a Kodeks uzupełnić tylko tam, gdzie on nie wyczerpuje istniejących potrzeb"100.

Synod plenarny odbył się w dniach 26-27 sierpnia 1936 roku w Częstochowie $^{101}$. Jego uchwały (w liczbie 151), nawiązujące generalnie do systematyki kodeksowej, zatwierdzone przez Kongregację Soboru i promulgowane 15 grudnia 1937 roku, zaczęły obowiązywać 16 czerwca 1938 roku $^{102}$.

\footnotetext{
${ }^{100}$ J. Zieliński, Pierwszy polski synod plenarny odrodzonej Rzeczpospolitej. Okres przygotowań, Prawo Kanoniczne 48(2005) nr 3-4, s. 265.

${ }^{101}$ Zob. W. Góralski, Przebieg pierwszego polskiego synodu plenarnego (1936) $w$ świetle protokołu synodalnego, Ateneum Kapłańskie 79(1987), z. 2, s. 335-342; A. DzIĘGA, Charakterystyka przebiegu i postanowień synodu plenarnego w Polsce w 1936 r., w: „Plenitudo legis dilectio”. Księga pamiątkowa dedykowana prof. dr. hab. Bronisławowi W. Zubertowi OFM z okazji 65. rocznicy urodzin, red. A. Dębiński, E. Szczot, Lublin 2000, s. 239-243; Zob. także W. GóRAlski, Korektury rzymskie w uchwałach pierwszego polskiego synodu plenarnego 1926 r., Prawo Kanoniczne 33(1990) nr 1-2, s. 153-173.

${ }^{102}$ Uchwały I. Polskiego Synodu Plenarnego odbytego w Częstochowie w dniach 26-27 VIII 1936, Poznań 1938.
} 
Jakkolwiek postanowienia synodu mają w znacznym stopniu charakter jurydyczny, to jednocześnie w swojej treści noszą na sobie znamię wybitnie duszpasterskie, czego szczególnym wyrazem jest wskazanie potrzeby aktywnej obecności wszystkich katolików w życiu Kościoła jako takiego, ale również w życiu wspólnot laikatu. Zgromadzenie to przyczyniło się niewątpliwie do odbudowy, porządkowania i pogłębiania życia społecznego, narodowego i państwowego w cieszącym się od 1918 roku niepodległością kraju. Niemałe znaczenie synodu polegało i na tym, iż przyczynił się do normatywnego uporządkowania i ujednolicenia wielu dziedzin życia kościelnego ${ }^{103}$. Trudno jednak przyznać synodowi, którego uchwały praktycznie nie zdążyły wejść w życie, szczególnej roli w dziele recepcji KPK, ta bowiem urzeczywistniała się za sprawą synodów diecezjalnych.

\section{Zakończenie}

Ogłoszenie przez Benedykta XV w 1917 roku KPK zapoczątkowało zupełnie nową erę w dziejach ustawodawstwa kanonicznego. Żmudny i trwający trzynaście lat proces kodyfikacji ius canonicum, obejmującej całą regulację prawną w sposób zupełny, jednolity i wyłączny, uwieńczony został sukcesem. Umiejętne powiązanie tego, co przez całe stulecia dobrze się sprawdziło we wspólnocie kościelnej, z tym, co rokowało nadzieję, że również będzie jej korzystnie służyć, zdawało się pomyślnie wróżyć nowo powstałemu zbiorowi.

Ius novissimum stało się prawdziwym wyzwaniem dla tych wszystkich, którym idea prawa w Kościele jest szczególnie bliska. Z natury rzeczy odnosiło się to przede wszystkim do biskupów poszczególnych Kościołów partykularnych, jako stróżów prawa w tych wspólnotach, a jednocześnie prawo to aplikujących, co więcej: jako ustawodawców w obrębie swoich jednostek organizacyjnych. W stosunku do regulacji KPK nie mogli pozostawać obojętnie również duchowni posługujący w administracji kościelnej i w sądownictwie kościelnym,

\footnotetext{
${ }^{103}$ A. DzIĘGA, Walor historyczny Pierwszego Synodu Plenarnego w Polsce z 1936 roku, w: Dzieło II Synodu Plenarnego w Polsce, red. S. Tymosz, Lublin 2001, s. 44$-45,47$ i 49.
} 
a także liczna rzesza duszpasterzy parafialnych. Od zainteresowania nowym prawem trudno wreszcie było wykluczyć wiernych świeckich, w odniesieniu do których wiele przepisów kodeksowych znajdowało swoją aplikację. Można więc powiedzieć generalnie, iż Kodeksem żywo zainteresowane były Kościoły partykularne, nie tylko zresztą z uwagi na konieczność dostosowania prawa własnego do nowo ogłoszonego prawa powszechnego.

Recepcja KPK w Kościołach partykularnych w Polsce, podobnie jak w innych krajach, dokonywała się w formie długotrwałego procesu, którego podstawowym etapem u nas był okres międzywojenny. Znaczącymi ogniwami tego procesu okazały się synody diecezjalne, umożliwiając nowelizację obowiązującego wówczas prawa diecezjalnego. Większość biskupów wykazała w tym zakresie znaczną aktywność, inicjując zgromadzenia synodalne. Ich statuty, uwzględniające nową regulację kodeksową, szeroko upowszechniane wśród duchowieństwa, stawały się jej właściwymi „nośnikami”.

Biskupi, ogół duchowieństwa i zainteresowani prawem kodeksowym wierni świeccy znajdowali nieocenioną pomoc w osobach przedstawicieli doktryny kanonistycznej. Zajmujący się ex professo prawem kanonicznym, jako dyscypliną naukową, poprzez swoje publikacje, przede wszystkim podręczniki i komentarze do KPK (lub do jego poszczególnych segmentów), znacząco przyczyniali się do recepcji norm kodeksowych. Szczególną powagę zyskał sobie obszerny i oparty na bogatym piśmiennictwie obcojęzycznym, całościowy komentarz F. Bączkowicza, a wcześniej o wiele skromniejszy podręcznik I. Grabowskiego. Gdy chodzi natomiast o warsztat naukowy, to największy rozgłos przypadł w udziale wyrafinowanemu komentarzowi (w języku łacińskim) zarówno do norm ogólnych KPK i do części ogólnej prawa osobowego, jak i do prawa karnego pióra G. Michielsa, wieloletniego profesora na Wydziale Prawa Kanonicznego Katolickiego Uniwersytetu Lubelskiego. Stan piśmiennictwa kanonistycznego w interesującym nas okresie generalnie wolno uznać za zadowalający.

Korzystnie przedstawiał się stan recepcji Kodeksu w nauczaniu ius canonicum na polskich uniwersytetach i w seminariach duchownych. 
Gdy chodzi o te pierwsze, to szczególne miejsce wypadnie tutaj przyznać Uniwersytetowi Jagiellońskiemu oraz Katolickiemu Uniwersytetowi Lubelskiemu. Co się tyczy zaś seminariów duchownych, to na szczególną uwagę zasługuje aktywność istniejącego od 1921 roku Związku Zakładów Teologicznych (Sekcja Prawno-Kanoniczna). Instytucja ta znacząco mobilizowała seminaryjnych wykładowców prawa kanonicznego do prowadzenia zajęć zgodnie z dokumentami Stolicy Apostolskiej i zasadami, niejednokrotnie innowacyjnymi, przyjętymi przez Związek. Chodziło wszak o jak najlepszą formację kanonistyczną przyszłych duszpasterzy opartą na normach KPK.

Uprawnione zatem wydaje się stwierdzenie, iż - mimo nieuniknionych mankamentów - złożony proces recepcji Kodeksu Prawa Kanonicznego trwający w latach 1918-1939 w Polsce prezentował poziom zadowalający. Dalszy etap tego procesu, nieoczekiwanie przerwanego wybuchem drugiej wojny światowej, nastąpił po roku 1945 i trwał generalnie - do Soboru Watykańskiego II.

\section{The reception of the Code of Canon Law of 1917 in Poland in the inter-war period}

Promulgation of the Code of Canon Law in 1917 by Benedict XV through a bull was a proud moment in the history of the legislation of the Latin Church. This formal collection of laws, which is a synthesis of legislative output of the Church of nineteen centuries, met with a lot of appreciation.

The entry into force of the Code of Canon Law (19 of May 1918) was a demanding task for local Churches operating in particular countries, inter alia for the Church in Poland. This included not only a thorough study of the regulations of the Code, especially by bishops, but also a necessity to adapt then existing particular law to these regulations. Therefore, the reception of the Code of Canon Law in particular Churches became necessary.

Assimilation of code standards by particular Churches, mainly through synods, took place in the context of increased activity of both a doctrine and centers in which canon law was taught. That is why when showing the process of reception of the Code of Canon Law in Poland in the above mentioned period (1918-1939), the author discusses its course in three fundamental areas in which it took place: in the canon doctrine (textbooks 
and comments to the Code of Canon Law), in the teaching of canon law (at universities and theological seminaries) and in particular Churches (with an example of Płock diocese).

SŁOWA KLUCZOWE: prawo kanoniczne; KPK; recepcja KPK; doktryna prawa kanonicznego; nauczanie prawa kanonicznego; ustawodawstwo partykularne

KEY WORDS: canon law; the Code of Canon Law; the reception of the Code of Canon Law; the doctrine of canon law; particular legislation

\section{NOTA O AUTORZE:}

Ks. PROF. ZW. DR hab. WOJCIECh GórAlSKi - pracownik naukowo-dydaktyczny na Wydziale Prawa Kanonicznego Uniwersytetu Kardynała Stefana Wyszyńskiego w Warszawie, kierownik Zakładu Kościelnego Prawa Rodzinnego. 